The Impact of High-Performance Work Systems on Employees: A Sectoral Comparison

Michael White

Alex Bryson

Department of Quantitative Social Science

Working Paper No. 19-04

August 2019 


\section{Disclaimer}

Any opinions expressed here are those of the author(s) and not those of the UCL Institute of Education. Research published in this series may include views on policy, but the institute itself takes no institutional policy positions.

DoQSS Workings Papers often represent preliminary work and are circulated to encourage discussion. Citation of such a paper should account for its provisional character. A revised version may be available directly from the author.

Department of Quantitative Social Science, UCL Institute of Education, University College London, 


\title{
The Impact of High-Performance Work Systems on Employees: A Sectoral Comparison
}

\author{
Michael White ${ }^{1}$ and Alex Bryson ${ }^{2}$
}

\begin{abstract}
Using nationally representative linked employer-employee surveys of workplaces with 50 or more employees we find the adoption of High-Performance Work Systems (HPWS) in the private sector is largely positively correlated with employee job attitudes pre-recession. However, high intensity HPWS has partly adverse consequences for private sector employees in the post-recession period. In contrast, there are no indications of public sector employees responding positively or negatively to HPWS and HPWS is not associated with adverse effects post-recession. The sectoral difference in results is interpreted in terms of different employment relationships and different sources of employee motivation.
\end{abstract}

JEL Codes: 131, J45, M5

Keywords: high performance work systems; public sector; organizational commitment; intrinsic job satisfaction; well-being

Contact Details: Alex Bryson (a.bryson@ucl.ac.uk), University College London, National Institute of Social and Economic Research and Institute for the Study of Labor

Acknowledgements: We would like to thank participants at the 2019 Royal Economics Society and a seminar at the University of Cardiff for comments on an earlier version of this paper

${ }^{1}$ University of Westminster

${ }^{2}$ University College London 


\section{Introduction}

Despite a large literature establishing links between employers' use of high-performance work systems (HPWS) and employees' job attitudes, none to our knowledge have compared these effects across the public and private sectors. This study using linked employer-employee data for Britain is the first to do so. The motivation comes from some recent reviews of HPWS research (or more generally of human resource management (HRM) research) that have emphasized the value of developing a contextual awareness (see, for instance, Boxall, 2013; Gould-Williams and Gatenby, 2010). 'Universalist' claims concerning impacts of HRM/HPWS, and perhaps especially the claims that such impacts are generally positive, may have been premature since little effort has been devoted to the investigation of varying contexts that are likely to moderate such impacts. By incorporating a contextual perspective into research, one hopes to progress toward a more differentiated and nuanced account of HRM/HPWS.

Our examination of context focuses on the nature of the employment relationship and of employee motivation in the public and private sectors, and on changing conditions that have faced managements in the two sectors as they attempt to develop HRM/HPWS to serve their organizational goals. We stress the importance of background (pre-HRM) conditions, that would either raise or lower the base level of employee motivation. One conjecture is that the scope for HRM/HPWS to influence employees' motivations in a positive way is greater when the initial level is relatively low.

As HRM/HPWS develop, they themselves become part of the context that affects both employees and employers. This is reflected in the notion of a threshold effect, whereby HRM/HPWS have large effects only once a certain implementation threshold has been reached (e.g. Becker and Huselid, 2006), and also in the 'strong system' theory of Bowen and Ostroff (2004), who argue that HRM needs to be developed in a multitude of ways in order to 'signal' effectively to employees. 
Some other authors have conversely argued that there may be an HRM/HPWS intensity threshold beyond which effects on employees taper off or even turn negative, especially through overwork demands and work-strain (Godard, 2001; Kroon et al., 2009; Ramsay et al., 2000; Spector, 2016). A contextualized perspective additionally suggests that HRM/HPWS effects on employees may be time-contingent, for instance interacting with short-run economic developments (e.g., business cycles or public sector funding policies) (Zatzick and Iverson, 2006).

The research with which we pursue these ideas has the following parameters. We use national surveys of British workplaces at two times, 2004 and 2011. Analysis is at the workplace level and thus primarily reflects the management perspective on HRM/HPWS effects. The comparisons are between the private and public sectors. We exclude from analysis any workplace that has less than 50 employees; we believe that small workplaces require a different theoretical approach (Storey et al., 2010). The outcomes we focus on are organizational commitment, intrinsic job satisfaction, well-being, and perceived communications with management. We analyse the effects on these attitudes of a measure of HPWS, comprising five main practice-domains. We reduce omitted variable bias (Gerhart, 2013) partly by using a large number of items in the construction of the HPWS variable, and partly by exploiting linked employer-employee data so as to average out (much of the) individual heterogeneity in employee attitudes. The linked data also help to minimize common method artefact (Gerhart, 2013; Podsakoff et al., 2005) since we can use management informants to define the HPWS measures and employee responses to define the attitudinal responses.

The remaining sections of this article are as follows. Section 2 conceptualizes how HPWS affect employee outcomes, while section 3 addresses contextual variations. Section 4 specifies hypotheses, section 5 the data and research methods. Section 6 presents results, and section 7 offers conclusions and some further implications of the research. 
There are two main new comparative findings of the research. The first is that while private sector employees' outcomes are sensitive to HPWS, public sector employees are indifferent to them. The second is that the effects of HPWS in the private sector are mainly positive in the booming British economy of 2004, but in the post-recessionary conditions of 2011 employees find there can be 'too much' HPWS.

\section{HRM/HPWS and effects on employees}

HRM loosely covers the range of people management and industrial relations functions exercised either by personnel/HR departments or by line managements. We define HPWS as systems of practice that constitute a subset of HRM, and form a suite intended to maximize organizational effectiveness. When HPWS are aligned to an organization's strategic position, it is common to refer to them as SHRM (strategic HRM). Our focus is on HPWS, but since the research literature often slides between HRM and HPWS we will often use the term HRM/HPWS when referring to previous discussions and findings.

There has been great variation in what researchers have designated as the contents of HPWS, in terms for instance of lists of operational practices. According to Appelbaum et al. (2000), whose exemplar we follow, key features are employee participation in problem-solving and change implementation processes, and team-working forms of work organization; these need to be 'supported' by recruitment/selection, training/development, and pay/reward. We call these 'HPWS domains', with each domain represented by a set or cluster of practice items. Participation and team-working domains provide the main value to employers, in performance terms: participation provides structures and processes whereby employees can contribute knowledge and information to problem solving and decision making, while team-working offers structures for group learning, collaboration and monitoring. The support domains are also important in supplying employees who are equipped and orientated for participative and collaborative work. For instance, appraisals not only provide reward to employees but also serve to align their personal work objectives with corporate goals or plans. 
Most discussions of HRM/HPWS emphasize the importance of combining the constituent practices and practice domains in ways that are mutually supportive and complementary. This is often termed 'bundling'. Bowen and Ostroff (2004) argue that to obtain a powerful effect from HRM it is necessary to implement a wide range of practices that in combination constitute a 'strong system', i.e. one that is capable of sending influential 'signals' to employees about the employer's aspirations and the organizational culture.

From an economic viewpoint, it is useful to think of HRM/HPWS practices being adopted by employers as an aspect of 'management technology' (Bloom et al., 2017). Such practices sit alongside other aspects of management technology such as monitoring and control systems, planning and target-setting. From the viewpoint of the present article, the chief point is simply that HPWS are developed by managements to serve organizational performance goals alongside other methods. However, employees must have sufficient goodwill toward their organization so that they engage cooperatively with HPWS activities. Thus motivation enters the frame, even if it is not the primary concern of employers.

Psychological theories of work motivation suggest how HPWS can have positive impacts. Following Fishbein (1967), we assume first that attitudes are essentially motivational. Fishbein regards attitude as a 'mediating evaluative response' that tends toward overt behavior. If this conceptual model is valid, one should observe links between attitudes and work behaviour. This link is confirmed by Harrison et al. (2006) with their meta-analysis showing that 'overall job attitude' explains about 25 per cent of the variation (i.e., r=0.50) in workers' 'engagement' behaviours (task performance, organizational citizenship, attendance, timeliness and reduced propensity to quit). The components of overall job attitude are job satisfaction and organizational commitment. A definition of job satisfaction that fits the general framework sketched above comes from Latham and Locke (1990: 243): 'The degree of satisfaction or dissatisfaction will be a joint function of the degree of fulfilment of the value and the importance 
of the value to the individual'. In simpler words, the more one gets something desired from work, the more satisfied one is. Organizational commitment then enters the frame, according to these authors, as a consequence of and complement to job satisfaction: 'Only if satisfaction leads to commitment to the organization and its goals ... will subsequent high performance result' (Latham and Locke, 1990: 245).

It remains to specify what is the desired value that HPWS can supply to employees. We suggest that this is increased autonomy or 'self-determination' (Gagné and Deci, 2005) . Notably, employees working within an HPWS framework in principle have increased opportunities to exercise influence on corporate decisions, to collaborate in operational problem-solving, and to perform varied work roles and tasks within teams. If these self-enhancing possibilities are realized in practice, there will be an increase of intrinsic job satisfaction and this will initiate the virtuous circle outlined by Latham and Locke (1990).

However, there has been a growing debate as to whether this positive interpretation of HPWS is realized in practice. Ramsay et al. (2000) deployed labour process theory to argue that HPWS was designed to extract higher levels of work effort from employees and was therefore likely to result in greater work strain. Godard (2001) reported negative effects of 'alternative work practices' on employees when those practices were present at a high intensity. Subsequently there have been numerous other studies exploring this territory, some deploying labour process theory, some a more psychological approach involving demand-resource imbalance (see Kroon et al., 2009, and the varied contributions in Ashkenasy et al., 2016).

The optimistic or positive view of HRM/HPWS has so far been largely supported in the empirical literature (see especially the meta-analysis of Jiang et al., 2012, that covers 116 studies). However, there are two limitations in most of this literature, that affect any metaanalysis based on it. First, it generally adopts a simple linear form: this excludes the possibility of 'too much' HRM/HPWS, as envisaged by Godard (2001) and subsequent critiques, and it 
also excludes the possibility of 'too little' HRM/HPWS, as suggested by 'threshold' models of effectiveness (e.g., Becker and Huselid, 2006) or by the 'strong system' theory of Bowen and Ostroff (2004). Second, it generally ignores contextual features that can moderate the effect of HRM/HPWS, such as the sectoral differences discussed in the next section. For instance, one can see from case studies that the positive effects of HRM/HPWS may be undone when external pressures lead management to act in ways that violate the implicit contract (e.g., Coyle-Shapiro and Kessler, 2000; Hailey et al., 2005). At a more macro level, Zatzick and Iverson (2006) use Canadian data covering a period of economic recession to show that positive effects of HRM/HPWS were sustained only by firms that avoided making lay-offs. ${ }^{3}$ Contrasting results were obtained in a study of HPWS in British small firms during another recessionary period: positive impacts on employees became clearer where the firm made wage or labour adjustments in response to the recession (Author A and Author B, date withheld).

\section{Contextual backgrounds}

\section{The private sector}

We conceptualize the employment relationship in the private sector as conflictual or contested, reflecting the fundamentally different interests of principals and their employees (Bowles and Gintis, 1993). In a neoclassical view different interests are resolved by a bargain that represents the best compromise available to the parties. In the radical economics perspective, however, this bargain fails to remove the conflict of interests and thus remains provisional and subject to continual renegotiation that takes place with shifts in relative power. In a sociological analysis, Etzioni (1975) characterized private sector employers as wielding 'remunerative power' to coordinate the work of employees with corporate aims, such that employees could only muster a kind of 'calculative commitment' to their jobs or employers. This implied that employees would exert effort in their jobs only to the extent they felt financially compensated.

\footnotetext{
3 The findings in Godard's (2001) study of Canadian employees may also have been affected by the Canadian recession of the late $1990 \mathrm{~s}$, although he does not refer to this himself.
} 
The idea of HRM emerged in the USA in the 1970s/80s in a context of alienated workers and highly controlling managements (e.g., Walton, 1972). The HRM concept was subsequently promoted as a way for the US private sector to cope with Japanese competition, aiming to unlock the problem-solving capacity of workers (Walton, 1987). At the early stage of development, US firms and researchers alike focused on the improvements in operational and financial performance that HRM promised. Appelbaum et al. (2000), who studied five manufacturing branches, were the first to assess impacts on employees' job satisfaction and commitment alongside of firm performance. Their results established a 'win-win' ( or 'mutual gains') interpretation of HPWS as a conventional wisdom. An alternative interpretation however is that this result may have reflected the low base level from which employee participation and agency were being lifted in US manufacturing (e.g., see Harrison and Bluestone, 1988).

During the late 1990s and through the 2000s there was a widespread adoption of HRM and HPWS practices in the private sector in Britain (Wood and Bryson, 2009; van Wanrooy et al., 2013). Over the same period there were numerous reports of increased pressures on the employment relationship in the private sector - generally to the disadvantage of employees such as increased precarity, work intensification, work-life imbalance, and earnings inequality (for reviews, see Green, 2006; McGovern et al., 2007: 6-28; Standing, 2011). Thus, the advance of HPWS can hardly be said to have been accompanied by any general positive change in employment relations. On the other hand, it may well be that against such a negative background HPWS provided private sector employees with some intrinsic satisfactions that they would value all the more.

The final tableau for us to consider is the profound financial-led recession of 2008, effects of which continued until at least 2013. Remarkably, consequences for the labour market were muted by comparison with the previous recession of the early 1990s. Job loss and unemployment remained at moderate levels. One plausible explanation (there are others) is that employers had come to understand the value of preserving their skill-base through the recession. 
Another salient feature of the recession was that most employers took steps to reduce labour costs, generally in the form of wage freezes, wage cuts or hours restrictions, and these steps were generally not resisted by employees. It is possible that habits of open discussion and consultation fostered by HPWS contributed to this compliance. Another interpretation is that wage flexibility was finally accepted by employees following a long process of 'softening up' through other forms of flexibility.

\section{The public sector}

The employment relationship is of a different type in the public sector. Public sector work is often extremely demanding (teaching, health services) or dangerous (police, fire-service), and it is carried out largely to help individuals who need care (children, sick, elderly, victims) or protection (crime, disaster). Etzioni (1975) characterized public sector workers as controlled by 'moral commitment', which he regarded as a more powerful influence on behaviour than the calculative commitment that prevails in the private sector. In a more everyday terminology, one could say that the motivational basis of the public service worker is vocational. Gallie et al. (1998: 240) note that 73 per cent of public sector employees strongly assent to the view that their organization is 'useful for society', while this applies to only 26 per cent of private sector employees.

The public sector has played a large part in the development of systematic personnel management. Farnham and Horton (1996) proposed that the British public sector is characterized by 'paternalism', with an emphasis on welfare provision and staff wellbeing (see also Russell, 1991, for historical examples); also by collectivism, with acceptance of high union density; and by a conscious policy of seeking to be 'model employers'. However, this tradition came under pressure during the 1980s with the advent of Thatcherism, and with criticism of the growing share of the public sector in the economy. Internationally, public services and public administration reached a critical juncture during the 1990s (Esping-Anderson, 1996). Underlying pressures came from demographic developments, notably increasing longevity and 
in-migration flows, and higher popular aspirations with respect to education, health, and consumption. These partly conflicting pressures led to demands for improved services, coupled (in Britain at least) with popular resistance to increased taxation. In response, British governments of both left and right persuasions have been asking the public services to 'do more with less' by operating more cost-effectively and by embracing various types of organizational and technical innovation. Another tendency, common to a number of countries, has been an advance of 'marketization' of the public sector through, for instance, outsourcing, competitive tendering and privatization (see, e.g., LeGrand and Bartlett, 1993). This suite of developments has been labeled the New Public Management (NPM) (see Burke et al., 2013 for international perspectives; Bach et al., 2009 for a British review). In broad terms, NPM would tend to reduce differences in the employment relationship between the private and public sectors.

In Britain, political pressure for cost reduction has been intense. During the 1990s the British public sector experienced a net loss of 800,000 jobs, 300,000 of which went in the single year 1993 (Hicks et al., 2005). After a few years of recovery during the early 2000s, further largescale cuts were initiated during the 'austerity' regime that followed the 2008 recession: current estimates suggest a cumulative reduction from 2008 of about one million jobs is in process. It is unclear however whether this process has been effectual, since staffing reductions may lead to reduced service levels. Official statistics show the British public sector in 2014 trailing behind France, Germany and the European Union average in terms of a conventional measure of productivity (ONS, 2017).

The development of HRM/HPWS in the British public sector in the past two decades has been steady (Cully et al., 1999; Kersley et al., 2006; Van Wanrooy et al., 2013). Bach et al. (2009: 324-9), looking across the late 1990s and early 2000s, discern a 'performance orientation' and emulation of private sector HRM/HPWS, but without curtailment of the traditional welfare emphasis in the public sector's policies. Moreover, unionization has remained at a high level, and unions have been an active and influential presence. Public perceptions of major 
institutions such as the NHS appear to remain favourable, and there have been frequent antigovernment protests against cuts under austerity. All told, public sector employees can continue to be reasonably confident in the value of their social role. Relative to that base, HRM/HPWS may seem a matter of slight importance, despite the much more severe implications (relative to the private sector) of the recession with respect to staffing levels.

Finally, one should note the substantial literature on work-strain and burnout in some of the public services (e.g., Hsieh et al., 2012). Jensen and Van De Voorde (2016) provide some evidence suggesting that HRM/HPWS can either exacerbate or ameliorate this type of problem. There is a case, then, for investigating effects of HPWS on employee well-being across sectors.

\section{Contextual hypotheses}

The hypotheses that we derive from our discussion are as follows.

H1a: We hypothesize that motivation, represented by organizational commitment (OC) and intrinsic job satisfaction (IJS), is positively related to HPWS in the private sector. This hypothesis is based on the previous literature (e.g., Jiang et al., 2012).

H1b: We hypothesize that the relationship of HPWS to motivation is less positive in the public sector than in the private sector, on the assumption that public sector employees derive a strong motivation from their social or vocational role (Etzioni, 1975) rendering HPWS practices relatively unimportant.

Further hypotheses relate to the relationship of economic circumstances to the HPWS effect. We conjecture that labour market pressures on employees, together with firms' cost-cutting policies in response to the recession, will modify the HPWS effect in the private sector, but on the basis of previous research this modification could take alternative forms:

$\mathrm{H} 2 \mathrm{a}$ - the pressures weaken any positive effect of HPWS. This could be either because economic circumstances increase work pressures, leading to a work-stress effect (Godard, 2001), 
or because employees find firms' cost-cutting initiatives are inconsistent with the positive intentions toward employees signalled by HPWS (Zatzick and Iverson, 2006)

Contrastingly, $\mathrm{H} 2 \mathrm{~b}$ postulates that firms' recessionary policies strengthen positive effects of HPWS, perhaps through a heightening of contrast (i.e., HPWS offers 'positives' for employees relative to a generally negative context) (e.g., Bryson and White, 2019).

We also hypothesize, consistent with $\mathrm{H} 1 \mathrm{~b}$, that public sector employees are less affected than in the private sector by change resulting from the recessionary experience, since their motivational basis is vocational rather than organizational $(\mathrm{H} 2 \mathrm{c})$.

We do not frame any hypotheses with respect to employee well-being, since the findings to date do note give clear guidance (see Jensen and Van de Voorde, 2016), but leave this as an aspect for exploratory investigation.

\section{Research methods - data, variables, analysis}

Data

We used two years, 2004 and 2011, of the Workplace Employment Relations Survey series (WERS). WERS covers the whole economy with the exception of agriculture, extraction, and micro-businesses (those with less than five employees). As noted in the Introduction, our analysis was confined to workplaces with at least 50 employees. Information was obtained through interviews with senior managers responsible for HRM. Further information on the WERS 2004 and 2011 surveys is available from the UK Data Archive and in Van Wanrooy et al. (2013).

The overall response rates for the WERS 2004 manager interview was 64 per cent. In WERS 2011, survey response was (like most other social surveys at this time) somewhat depressed, with a management response rate of 46 per cent. However, the total sample size was increased in 
2011 vis-a-vis 2004. In both years a postal questionnaire survey of a random sample of 25 employees per workplace was conducted shortly after the management interview was completed. Employee data were obtained from 61 per cent of sampled employees in 2004, and 50 per cent in 2011. Since the analysis conducted here uses employee outcome data, only workplaces with linked employer-employee data are used. Subsample numbers available for the analyses were: in 2004, private sector 591, public sector 393, and in 2011, private sector 498 and public sector 581. The public sector formed a larger proportion of the sample in 2011 than in 2004 (its proportion rising from approximately 30 per cent to 40 per cent).

\section{Dependent variables}

We assessed motivation through the concept of overall job attitude (Harrison et al. 2006), consisting of two variables that we label intrinsic job satisfaction (IJS) and organizational commitment (OC). IJS was derived from four facet satisfaction items that were closely similar to the 'job itself intrinsic satisfaction' subscale of Warr et al. (1979). The measure of OC consists of three items that have counterparts in the six-item Lincoln-Kalleberg measure of affective organizational commitment.

Alongside motivation, a further employee outcome to be considered is affective wellbeing. The WERS surveys address this concept through a list of feelings that employees may have experienced in their work; the employee is asked to report 'how frequently'. An unfortunate complication is that the lists differed between years. In 2004, well-being was derived from a sixitem list with three negative feelings and three positive. In 2011 all six items were negative feelings. The latter would tend to increase response set, and consistent with this reliability alpha rose from 0.85 in 2004 to 0.91 in 2011 , with mean response shifting away from the central position. In both years, as with other measures, we recoded responses in such a way that the score would measure positivity. To keep the difference in well-being measures in mind, we label them with year subscripts. 
Three further measures were included to aid interpretation. A measure of perceived communications was derived from a sequence of seven opinion items (covering both downward and upward communications). Inclusion of this measure relates to the interpretation of HPWS as a communications or 'signalling' system (Bowen and Ostroff, 2004). A measure of trust was derived from five items relating to opinions about management. This is mainly for comparison with Appelbaum et al. (2000) who argued that trust was a condition for commitment. Finally, we constructed a measure of extrinsic job satisfaction (EJS), derived from three facet satisfaction items (pay, job security, training); this serves a methodological purpose, since a less-positive effect of HPWS on EJS strengthens discriminant validity for the IJS effect.

Each of these items was calculated by summing a score per employee and then averaging across employee respondents at each workplace. These mean employee outcome variables were then linked to the workplace (management interview) data that provided the HPWS measure and the control variables (see below).

The use of mean employee outcome measures has several advantages. Averaging results in smooth quasi-continuous measures that are suitable for regression analysis. From a practical viewpoint, management presumably is concerned about motivations and other attitudes across all employees, and that is what these measures indicate. Averaging also addresses the problem of individual heterogeneity bias in attitudinal responses that is associated with unmeasured and persistent personality and cognitive style attributes (see Diener and Lucas, 1999). Since employers have no reliable means of measuring personality at selection interview, it can reasonably be assumed that a random sample of employees also represents a random sample of personality attributes with mean-zero bias. In practice, of course, one does not obtain a sample of all employees, but only a sample of stayers, that involves (self-)selection processes over time. None the less, one can reasonably expect that unobserved variable bias will be reduced by the averaging process, by comparison with an analysis at the individual level.

See Appendix Table 1 for details of the outcome variables and their reliabilities. 


\section{Explanatory variable}

The explanatory variable was a summative index of HPWS practices. In the HRM-performance literature HPWS items have usually been aggregated into a single overall index of practices (e.g., Becker and Huselid (1998:63)), and we followed this method. We included only items that are descriptive of current practice and ignored any items that sought the manager's opinion about workplace climate, management-employee relations etc. Altogether 43 items (each item representing one practice) were used in 2004, and 44 in 2011, a larger number than in most other studies of HPWS/HRM (Ramsay et al., 2000, and Guest et al., 2003, also used large sets of items). There were detailed differences between the item-lists across years, but sufficient similarity to maintain conceptual consistency. In each year, items were first grouped into five 'domains' (participation, team-working, training and development, recruitment/selection, and performance pay) that were tested and refined by reliability analysis prior to pooling (see Appendix Table 2). An advantage of using a large set of items/practices is that this reduces the risk of omitted variable bias.

While many items were of the simple 'present/absent' type, others were derived by reducing a quantified banded variable (such as proportion of employees taking part in the practice, or time devoted to the practice) to dichotomous form by splitting at the overall median, an efficient method of removing measurement error. Note also that while some items referred to fairly basic HRM practices, others can be regarded as toward the sophisticated extreme: for instance, teams that select their own leader, or communication meetings that discuss staffing levels or finances.

Empirical support for adopting a summative index as the HPWS measure has been provided by Combs et al. (2006), who concluded from their meta-analysis of the HPWS-performance relationship that summative scores have been about twice as predictive of outcomes as use of separate measures. Wood and de Menezes (2011) have criticized the use of summative measures on the grounds that they obscure the operation of conceptually distinct configurations within 
HPWS. Arguments lending theoretical support for the summative approach can be found in Becker and Huselid (2006).

See Appendix Table 2 for details of the explanatory variables.

\section{Control variables}

All explanatory analyses included control variables of a standard type. Structural variables were workplace size - the log of the number of employees, and size of parent organization, with sizegroups less than 1000 employees, 1000-999, and 10,000-plus, compared with single-site as the reference category. Industrial relations structure was represented by a trichotomous variable (no union, one, more than one $)^{4}$. Age of workplace had four categories (0-4 years, 5-9, 10-24, and 25-plus). Compositional variables were percentages of female employees, of part-time employees, of those on fixed-term contracts, and of those in 'higher' and 'lower' occupational/skill categories with 'intermediate' as the reference category. A difficulty that arose with the control variable for industry group was that certain industries had very few private sector workplaces while others had very few public sector workplaces. The public sector was described through five groups - commercial services (mainly but not exclusively in transport and communications), public administration (includes government, police, and emergency services), education, healthcare, and community services (mostly cultural, leisure and sports). For the private sector we split commercial services into manufacturing, utilities, construction, distribution, hospitality, transport/communications, financial services, and business services, while amalgamating public administration, education, health, and community services into one group.

An additional control variable, for 2011 only, was based on workplaces' adoption of cost-cutting labour policies, such as wage freezes, wage cuts and short-time working, in response to the 2008

\footnotetext{
${ }^{4}$ For the public sector, multi-unionism provides a more sensitive measure than simple union recognition, because unions are recognized throughout most of the public sector. Variant analyses using union membership density were also carried out but led to no increase in explanatory power.
} 
recession. A dummy variable was scored 1 if the workplace reported using three or more such policies, and 0 otherwise. This criterion was reached by 25 per cent of private sector workplace and 31 per cent of the public sector workplaces (weighted basis).

A table of descriptive statistics for the control variables is available on request.

\section{Analysis methods}

All analyses were carried out by robust regression (Berk, 1990). This differs from ordinary regression in that the computation of standard errors takes account of survey weighting and complex survey design, and generally yields somewhat conservative inferences by comparison with OLS. Analyses were performed separately for the sector subsamples. This was necessary because of the different industry-group variables by sector (see above), but has the advantage that the covariance structure is allowed to be flexible across sector.

The regressions were carried out using two alternative specifications in the HPWS variable: (1) linear, (2) linear-quadratic, i.e. the HPWS index score accompanied by HPWS-squared. However we present the results of the linear-quadratic specifications only where they lead to a different conclusion to the corresponding linear specification. Results for the complete set of linearquadratic models are available on request, as are any other results referred to in the text but not reported in tabular form.

\section{Results}

Table 1 below summarizes results for the year 2004 across the whole set of employee outcomes and for both sectors. Only the estimated effects of the HPWS-index variable are shown, but all of these results are drawn from analyses with the complete set of control variables. Each row of results refers to a separate outcome. Results for the private sector are divided into two panels, with panel (a) reporting estimates from linear specification of HPWS and panel (b) reporting 
estimates from linear-quadratic specifications. However panel (b) is left blank in rows where the linear-quadratic model has nothing of interest to tell us relative to the panel (a) results.

The right-hand side of Table 2 shows estimates for the public sector. Only the results for the linear specification of HPWS are shown (i.e., those that correspond to panel (a) for the private sector). The linear-quadratic models were run for the public sector but never offered anything of interest. For that matter, the linear models for the public sector never produced estimates that were significantly different (at conventional levels) from zero.

The main purpose of the research lay in sectoral comparisons, and from that perspective the table contained several points of interest. $\mathrm{OC}$ in the private sector increased positively and significantly with HPWS. The other element of our motivational concept, namely IJS, did not have a positive linear relationship to IJS, but the linear-quadratic specification showed IJS was increasing across workplaces attaining higher levels of HPWS (the turning-point implied by the estimates is at 21 on the HPWS index, somewhat below the sectoral mean of 23.7). Perceived communications were also rather strongly influenced by HPWS, offering some support to the signalling interpretation of HPWS effects. However none of these HPWS effects emerged in the public sector analyses. It is not possible to apply a statistical test across sectors, because the specifications differed in the representation of industry groups (see section 5 above). However, one may reasonably conclude in a qualitative sense that private sector employees were more receptive to, or sensitive to, HPWS practices than were public sector employees in year 2004.

The results with respect to the effect of HPWS on well-being lent no support to the contention that HPWS is damaging in this respect. All estimates across both sectors yielded non-significant estimates, and this included the linear-quadratic specifications where an effect of high-intensity HPWS might have been expected to appear.

Table 1 HPWS effects on attitudinal outcomes in year 2004

\begin{tabular}{|l|l|l|l|l|l|l|}
\hline \multicolumn{4}{|c|}{ Private sector } & \multicolumn{2}{l|}{ Public sector } \\
\hline Model> & (a) linear & (b) linear-quadratic & \multicolumn{2}{l|}{ linear } \\
\hline Outcomes: & b (s.e) & R-sq & linear b (s.e.) & quadratic b (s.e) & b (s.e) & R-sq \\
\hline
\end{tabular}




\begin{tabular}{|l|l|l|l|l|l|l|}
\hline OC & $0.034(0.010)^{* *}$ & 0.160 & & & $0.003(0.016)$ & 0.378 \\
\hline trust & $0.025(0.025)$ & 0.181 & & & $0.035(0.039)$ & 0.298 \\
\hline IJS & $-0.003(0.015)$ & 0.127 & $-0.109(0.062)+$ & $0.0026(0.0014)+$ & $-0.001(0.021)$ & 0.221 \\
\hline EJS & $0.011(0.013)$ & 0.170 & & & $0.005(0.016)$ & 0.240 \\
\hline well-being 04 & $-0.012(0.019)$ & 0.221 & & & $0.006(0.178)$ & 0.226 \\
\hline perceived communications & $0.139(0.039)^{* *}$ & 0.215 & & & $-0.020(0.058)$ & 0.237 \\
\hline
\end{tabular}

Notes: Weighted regression analyses with a robust variance estimator. All analyses included full controls as described in text (section 5). $\mathrm{N}$ for private sector analyses is $578, \mathrm{~N}$ for public sector analyses is 362 . Estimate significantly different from zero: + at the 10 per cent level $*$ at the 5 per cent level $* *$ at the 1 per cent level

Table 2 shows the corresponding results from year 2011. Recall that these analyses included an additional control variable, a dummy indicating that the workplace had adopted three or more cost-cutting labour policies (affecting wages, hours) in response to the 2008 recession. In the public sector sample there was no indication that anything had changed in respect of the effect of HPWS on employee outcomes, which remained near-zero everywhere. However there were considerable changes in the picture for the private sector. The linear effect of HPWS on OC that was observed in 2004 was replaced by a non-linear effect (see panel (b) of Table 2). The estimates showed OC increasing up to moderate levels of HPWS intensity, but declining again above that. A very similar picture applied both to the measure of trust in management and to the measure of perceived communications. In each case, the effect of HPWS became negative above the sectoral median of HPWS intensity. Overall, the results suggested that in 2011 employees were less happy when there were above-average levels of HPWS. This inverted-U form of relationship between HPWS and motivational measures was somewhat similar to that reported by Godard (2001) with Canadian employees.

Furthermore, in the private sector there was a significant negative and linear effect of HPWS on employee well-being (it should be recalled that the measure of wellbeing in 2011 differed from 2004's). Overall, these results indicated that for private sector employees in 2011 there could well be 'too much' HPWS. ${ }^{5}$

\footnotetext{
5 This picture contrasts sharply with a previous analysis of small firms (those with less than 50 employees), where there were positive effects of HPWS on both OC and IJS (Bryson and White, 2019).
} 
Comparing across sectors, we conclude (as in 2004) that private sector employees were more responsive, or sensitive, to HPWS than were public sector employees. However, this responsiveness in 2011 included a partially negative side whereas in 2004 it had a predominantly positive sense. Both sectoral contexts and time-specific contexts are moderators of HPWS effects.

Table 2 HPWS-index effects on attitudinal outcomes in year 2011

\begin{tabular}{|c|c|c|c|c|c|c|}
\hline \multicolumn{5}{|c|}{ Private sector } & \multirow{2}{*}{\multicolumn{2}{|c|}{$\begin{array}{l}\text { Public sector } \\
\text { linear }\end{array}$}} \\
\hline Model $>$ & (a) linear & & (b) linear-quadra & & & \\
\hline Outcomes: & b (s.e) & R-sq & linear b (s.e.) & quadratic b (s.e) & $\mathrm{b}$ (s.e) & R-sq \\
\hline $\mathrm{OC}$ & $-0.002(0.015)$ & 0.253 & $0.143(0.071)^{*}$ & $-0.003(0.0015)^{*}$ & $0.003(0.012)$ & 0.401 \\
\hline trust & $0.016(0.029)$ & 0.268 & $0.249(0.132)+$ & $-0.005(0.003)+$ & $-0.007(0.0340$ & 0.349 \\
\hline IJS & $0.003(0.015)$ & 0.278 & & & $-0.005(0.018)$ & 0.312 \\
\hline EJS & $0.007(0.015)$ & 0.137 & & & $-0.0005(0.014)$ & 0.283 \\
\hline well-being ${ }_{11}$ & $-0.066(0.022)^{* *}$ & 0.157 & & & $0.019(0.031)$ & 0.167 \\
\hline perceived communications & $0.030(0.040)$ & 0.226 & $0.393(0.160) * *$ & $-0.008(0.003)^{*}$ & $0.035(0.041)$ & 0.250 \\
\hline
\end{tabular}

Notes: Weighted regression analyses with a robust variance estimator. All analyses included full controls as described in text (section 5). $\mathrm{N}$ for private sector analyses is $477, \mathrm{~N}$ for public sector analyses is 512 . Estimate significantly different from zero: + at the 10 per cent level * at the 5 per cent level $* *$ at the 1 per cent level

An obvious line of further inquiry is whether the adoption of labour cost-cutting policies in response to the recession could have adversely impacted the value of HPWS practices to employees. However, the main effect of the recessionary-policy dummy, although always of negative sign, did not reach significance at conventional levels across the whole set of employee outcomes in the private sector. ${ }^{6}$ An alternative specification with an interaction between HPWS and recessionary policy also yielded a significant result only in the case of IJS: HPWS had a positive effect on IJS only if the workplace had adopted cost-cutting policies, ${ }^{7}$ so offers no support for the idea that cost-cutting is a bad combination with HPWS.

\footnotetext{
6 There was one significantly negative effect of the recessionary policy variable in the public sector: this was for OC $(b=-0.267$, s.e. $=0.129, \mathrm{t}=2.06)$.

7 The interaction shows HPWS having $b_{0}=-0.011$ (s.e. $\left.=0.016\right)$ and $b_{1}=0.063$ (s.e. $=0.029$ ), where the subscripts refer to the absence $(0)$ or presence $(1)$ of the recessionary policies.
} 
We earlier conjectured that public sector employees would be less motivated by HPWS than private sector employees. Not being motivated by HPWS does not however imply not being motivated at all; it may equally suggest that motivation is different. One way of checking this is to examine the raw (i.e. unadjusted for HPWS and other covariates) means on the employee outcome variables, by sector. Table 3 shows these means with their standard errors.

In 2004, public sector workplaces had at least as high (positive) scores on all employee outcome measures as did private sector workplaces. Mean OC was indeed significantly higher in the public sector and mean well-being was particularly high there. In 2011, differences had generally shrunk; in some instances the private sector had a somewhat higher mean but none of the differences was statistically significant. Overall, one can assert that the public sector workplaces recorded levels of motivation and well-being as high as in the private sector, despite not experiencing any of the positive effects of HPWS that the private sector had.

Table 3 Workplace means of attitudinal outcomes for 2004 and 2011, by sector

\begin{tabular}{|l|l|l|l|l|}
\hline Cell figures are weighted mean (s.e.) & \multicolumn{2}{|l|}{2004} & \multicolumn{2}{l|}{2011} \\
\hline Sector $>$ & Private & Public & Private & Public \\
\hline Outcomes: & & & & \\
\hline OC & $10.84(0.08)$ & $11.24(0.08)$ & $11.30(0.08)$ & $11.50(0.08)$ \\
\hline trust & $19.73(0.18)$ & $20.03(0.19)$ & $20.25(0.20)$ & $19.99(0.19)$ \\
\hline IJS & $14.78(0.09)$ & $14.96(0.10)$ & $15.18(0.11)$ & $15.20(0.11)$ \\
\hline EJS & $9.73(0.08)$ & $9.75(0.08)$ & $9.88(0.09)$ & $9.70(0.08)$ \\
\hline well-being ${ }_{04}$ & $15.30(0.13)$ & $18.91(0.14)$ & --- & --- \\
\hline well-being 11 & --- & --- & $23.86(0.17)$ & $23.61(0.16)$ \\
\hline perceived communications & $21.63(0.24)$ & $22.15(0.30)$ & $22.90(0.26)$ & $22.51(0.23)$ \\
\hline N & 591 & 393 & 498 & 531 \\
\hline
\end{tabular}

\section{Conclusions and Implications}

This research embarked with the idea that the effects of HPWS on employees are moderated by the contexts in which HPWS operate. To investigate this conjecture we conducted analyses by 
sector (private $\mathrm{v}$ public) and by time-period (boom-time $\mathrm{v}$ recession), with HPWS as the explanatory variable for a range of employee outcomes. The investigation was focused upon medium-sized and large workplaces.

The direct conclusions that can be drawn from the research results are largely (but not wholly) supportive of the hypotheses set out in section 4. Because of unavoidable differences in analysis specifications between sectors and across years, these conclusions do not emerge from formal statistical tests but from qualitative assessment of results.

The private sector in 2004 provides evidence in support of hypothesis H1a: OC increases with HPWS intensity, and IJS increases with HPWS once above-average HPWS has been reached. There is also a positive effect of increasing HPWS on employee views of workplace communications, a result that strengthens the interpretation of HPWS as a 'signalling' system. Hypothesis H1b predicted that employee motivation in public sector workplaces would be less affected by HPWS than in the private sector, and this too was supported - indeed there was no sign of public sector employees responding positively to HPWS across the range of outcomes. The basis of the prediction here was that public sector motivation tends to be 'vocational' rather than organizational. Of course this interpretation remains speculative in the absence of measures that directly address vocational motivation.

We then used 2011 data to assess what happened when the economic environment deteriorated for employees. In the private sector, the findings supported $\mathrm{H} 2 \mathrm{a}$, with OC, trust, and communications all taking on an inverted-U relationship to HPWS: in other words, these outcomes were increasing up to moderate levels of HPWS but this relationship was reversed at higher HPWS intensity. Private sector employees were finding that there could be 'too much' HPWS in the conditions of 2011. Moreover, HPWS was associated with declining well-being in the private sector, a relationship not found in 2004. 
Finally, hypothesis H2c, predicting that public sector employees would be less affected by the changed economic circumstances, was supported by the 2011 evidence. Public sector employees appeared not to experience even the limited positive impact of HPWS on commitment and satisfaction that remained in the private sector of 2011. On the other hand, nor did they experience the negative pressure from HPWS on well-being that was then present in the private sector. One can perhaps attribute this to the protection provided by the traditional welfare orientation of the public sector (Bach et al, 2009).

The findings, taken as a whole, reinforce a call for more attention to be paid to contextual differences (Boxall, 2013) rather than assuming the 'universalist' view of HPWS. A case can perhaps be made for universal effects of HPWS on organizational performance, in the sense that the chief practices of HPWS are simply part of 'good management' (Bloom et al., 2017). ${ }^{8}$ But to extend the universalist case to employee outcomes is to ignore the diversity of interests and the differences in starting positions from which groups respond to HPWS.

Adopting a more contextual perspective should encourage the construction of wider-ranging survey questions in organizational surveys. Relevant questioning on diverse motivations might be found in such sources as the World Values surveys, or in studies of organizational climate that take account of external roles and relations (e.g. Cavrini et al, 2015; Mosatafa et al, 2015). Also relevant are the types of opinion questions relating to economic change and socio-economic institutions in the British Attitudes Surveys and the European Social Surveys. In short, workplace research, including research on HPWS, needs to think outside the workplace box if it is to make headway in understanding motivational contexts.

\footnotetext{
${ }^{8}$ In a companion paper using the same datasets (Author A and Author B,date withheld), we show that HPWS had significantly positive effects on workplace performance in the public sector as assessed by financial performance ratings and achievement of change in technology and work organization.
} 


\section{References}

Appelbaum, E., Bailey, T., Berg, P. and Kalleberg, A.L. (2000) Manufacturing advantage: Why high-performance work systems pay off, Ithaca NY: Cornell University Press.

Bach, S., Givan, R. and Forth, J. (2009) 'The Public Sector in Transition' in Brown, W., Bryson, A., Forth, J. and Whitfield, K. (eds.) The Evolution of the Modern Workplace, Cambridge: Cambridge University Press: 307-31.

Becker, B.E. and Huselid, M.A. (1998) 'High performance work systems and firm performance: A synthesis of research and managerial implications'. In Ferris, G.R. (ed.) Research in personnel and human resources management, Vol. 16, Stamford, CT: JAI Press: 53-101.

Becker, B.E. and Huselid, M.A. (2006) Strategic human resources management: where do we go from here?, Journal of Management, 32(6): 898-925.

Berk, R.A. (1990) 'A Primer on Robust Regression', in Fox, J. and Long, J.S. (eds.) Modern Methods of Data Analysis, Newbury Park, CA: Sage: 292-324.

Bloom, N., Sadun, R., and Van Reenen, J. (2017) Management as a Technology? CEP Discussion Paper 1433 (revised), London: Centre for Economic Performance.

Bowen, D.E. and Ostroff, C. (2004) Understanding HRM-performance linkages: The role of the “strength" of the HRM system, Academy of Management Review, 29(2): 203-21.

Bowles, S. and Gintis, H. (1993) The Revenge of Homo Economicus: Contested Exchange and the Revival of Political Economy, Journal of Economic Perspectives 7(1):83-102. 
Boxall, P. (2013) 'Building High-Performing Work Systems: Analysing HR Systems and Their Contribution to Performance', in Paauwe, J., Guest, D., and Wright, P. (eds) HRM and Performance: Achievements and Challenges, Chichester: Wiley: 47-59.

Burke, R.J., Allisey, A.F., and Noblet, A.J. (2013) 'The importance of human resource management in the public sector, future challenges and the relevance of the current collection', in Burke, R.J., Noblet, A.J., and Cooper, C.L. (eds.) Human Resource Management in the Public Sector, Cheltenham: Edward Elgar : 1-13.

Cavrini, G., Chianese, G., Boch, B., and Dozza, L. (2015) School Climate: Parents', Students' and Teachers' Perceptions, Procedia - Social and Behavioral Studies, special issue of the $6^{\text {th }}$. World Conference on Educational Sciences, 191 (June) 2044-8.

Combs, J., Liu, Y., Hall, A., and Ketchen, D. (2006) How much do high performance work practices matter? A meta-analysis of their effects on organizational performance, Personnel Psychology, 59(3): 501-28.

Coyle-Shapiro, J. and Kessler, I. (2000) Consequences of the Psychological Contract for the Employment Relationship: A Large-Scale Survey, Journal of Management Studies, 37(7): 90329.

Cully, M., Woodland, S., O'Reilly, A. and Dix, G. (1999) Britain at Work: As depicted in the 1998 Workplace Employee Relations Survey, London: Routledge.

Diener, Ed and Richard E. Lucas. (1999) 'Personality and Subjective Well-Being', in Daniel Kahneman Ed Diener, and David N. Schwartz (eds.) Well-Being: The Foundations of Hedonic Psychology, New York: Russell Sage Foundation: 213-229. 
Esping-Andersen, G, (1996) 'After the Golden Age? Welfare State Dilemmas in a Global Economy', in Esping-Andersen, G. (ed.) Welfare States in Transition: National Adaptations in Global Economies, Thousand Oaks, CA: Sage.

Etzioni, A. (1975) A Comparative Analysis of Complex Organizations, revised and enlarged edition, New York: Free Press.

Farnham, D. and Horton, S. (1996) 'Continuity and Change in the Public Services' in Farnham, D. and Horton, S. (eds.) Managing People in the Public Services, Basingstoke: Macmillan : 3-42.

Fishbein, Martin (1967) 'A Behavior Theory Approach to the Relations between Beliefs about an Object and the Attitude Toward the Object', in Martin Fishbein (ed.) Attitude Theory and Measurement, London; John Wiley \& Sons: 389-400.

Gagné, Marylène and Edward L. Deci (2005) 'Self-determination theory and work motivation', Journal of Organizational Behavior, 26(4): 331-62.

Gallie, D., White, M., Cheng, Y. and Tomlinson, M. (1998) Restructuring the Employment Relationship, Oxford: Oxford University Press.

Gerhart, B. (2013) 'Research on Human Resources and Effectiveness: Some Methodological Challenges' in Paauwe, J., Guest, D., and Wright, P. (eds) HRM and Performance: Achievements and Challenges, Chichester: Wiley: 149-71.

Godard, J. (2001) High Performance and the Transformation of Work? The Implications of Alternative Work Practices for the Experience and Outcomes of Work, Industrial and Labor Relations Review, 54(4): 776-805. 
Gould-Williams, J.S. and Gatenby, M. (2010) The effects of organizational context and teamworking activities on performance outcomes, Public Management Review 12(6):759-87.

Green, F. (2006) Demanding Work: The Paradox of Job Quality in the Affluent Economy, Woodstock: Princeton University Press.

Guest, D.E., Michie, J., Conway, N. and Sheehan, M. (2003) Human Resource Management and Corporate Performance in the UK, British Journal of Industrial Relations, 41(2): 291-314.

Hailey, Veronica H., Elaine Farndale and Caherine Truss. (2005) 'The HR Department's Role in Organisational Performance', Human Resource Management Journal, 15(3): 49-66.

Harrison, B. and Bluestone, B. (1988) The Great U-turn: Corporate Restructuring and the Polarizing of America, New York: Basic Books.

Harrison, D.A., Newman, D.A. and Roth, P.L. (2006) How Important are Job Attitudes? Metaanalytical Comparisons of Integrative Behavioral Outcomes and Time Sequences, Academy of Management Journal, 45(2): 305-325.

Hicks, A., Walling, A., Heap, D. and Livesey, D. (2005) Public Sector Employment Trends 2005, London: National Statistics.

Hsieh, C.-W., Jin, M., and Guy, M.E. (2012) Consequences of work-related emotions: analysis of a cross-section of public sector workers, American Review of Public Administration, 42(1): $39-53$.

Jensen, J.M. and Van De Voorde, K. (2016) 'High Performance at the Expense of Employee Health? Reconciling the Dark Side of High Performance Work Systems' in Ashkenasy, N.M., 
Bennett, R.J. and Martinko, M.J. (eds.) Understanding the High Performance Workplace: The Line Between Motivation and Abuse, New York, NY: Routledge: 148-69.

Jiang, K., Lepak, D.P., Hu, J. and Baer, J.C. (2012) How Does Human Resource Management Influence Organizational Outcomes? A Meta-Analytic Investigation of Mediating Mechanisms, Academy of Management Journal 55(6): 1264-94.

Kersley, B., Alpin, C., Forth, J., Bryson, A., Bewley, H., Dix, G. and Oxenbridge, S. (2006) Inside the Workplace: Findings from the 2004 Workplace Employment Relations Survey, London: Routledge.

Kroon, B., van de Voorde, K. and van Veldhoven, M. (2009) Cross-level effects of high performance work practices on burnout: Two counteracting mediating mechanisms compared, Personnel Review, 38(5); 509-25.

LeGrand, J. and Bartlett, W. (eds.) Quasi-Markets and Social Policy, London: Macmillan.

Latham, G.P. and Locke, E.A. (1990) Work Motivation and Satisfaction: Light at the End of the Tunnel, Psychological Science, 1 (4): 240-6.

McGovern, P., Hill, S., Mills, C. and White, M. (2007) Market, Class, and Employment, Oxford: Oxford University Press.

Mostafa, A.M.S., Gould-Williams, J.S. and Bottomley, P. (2015) High Performance Human Resource Policies and Employee Outcomes: The Mediating Role of Public Service Motivation, Public Administration Review, 75(5): 747-57. 
ONS (2017) International Comparisons of Labour Productivity by Industry: 2014, London: Office of National Statistics web article, released $6^{\text {th }}$ October 2017.

Podsakoff, Philip M., Scott B. MacKenzie, Joong-Yeon Lee, and Nathan P. Podsakoff (2003) Common Method Biases in Behavioral Research: A Critical Review of the Literature and Recommended Remedies, Journal of Applied Psychology, 88(5): 879-903.

Ramsay, H., Scholarios, D. and Harley, B. (2000) Employees and high-performance work systems: Testing inside the black box, British Journal of Industrial Relations, 38(4): 501-32.

Russell, A, (1991) The Growth of Occupational Welfare in Britain: Evolution and Harmonization of Modern Personnel Practice, Aldershot: Avebury.

Spector, P.E. (2016) 'When More Can Become Less: High Performance Work Systems as a Source of Occupational Stress', in Ashkenasy, N.M., Bennett, R.J. and Martinko, M.J. (eds.) Understanding the High Performance Workplace: The Line Between Motivation and Abuse, New York, NY: Routledge: 148-69.

Standing G. (2011) The Precariat: The New Dangerous Class. London: Bloomsbury.

Storey, D., Saridakis, G., Sen-Gupta, D., Edwards, P. and Blackburn, R.A. (2010) Linking HR Formality with Employee Job Quality: The Role of Firm and Workplace Size, Human Resource Management, 49(2): 305-29.

van Wanrooy, B., Bewley, H., Bryson, A., Forth, J., Freeth, S., Stokes, L., and Wood, S.(2013) Employment Relations in the Shadow of Recession, Basingstoke: Palgrave Macmillan.

Walton, R.E. (1972) 'How to counter alienation in the plant', Harvard Business Review, 72 No. 6: $70-81$. 
Walton, R.E. (1987) Innovating to Compete, London: Jossey-Bass.

Warr, P., Cook, J. and Wall, T. (1979) Scales for the measurement of some work attitudes and aspects of psychological wellbeing, Journal of Occupational Psychology, 52(2): 129-48.

Wood, S. and Bryson, A. (2009) 'High involvement management', Chapter 7 in W. Brown, A. Bryson, J. Forth and K. Whitfield (eds.) The Evolution of the Modern Workplace, pp. 151-175, Cambridge University Press

Wood, S. and de Menezes, L.M. (2011) High involvement management, high-performance work systems and wellbeing, International Journal of Human Resource Management, 22 (7): 15861610.

Zatzick, Christopher D. and Roderick D. Iverson (2006) High-involvement management and workforce reduction: Competitive advantage or disadvantage?, Academy of Management Journal, 49(5): 999-1015. 


\section{Appendix Tables}

\section{Appendix Table 1 Dependent Variables}

\begin{tabular}{|c|c|c|c|c|c|c|c|c|}
\hline & & \multicolumn{3}{|l|}{2004} & \multicolumn{3}{|l|}{2011} & \\
\hline & range & mean & s.d. & $\mathrm{N}$ & mean & s.d. & $\mathrm{N}$ & Items \\
\hline IJS scale & $4-20$ & 14.69 & 1.34 & 984 & 15.00 & 1.42 & 1079 & $\begin{array}{l}\text { (Satisfaction with..) Sense of achievement from your } \\
\text { work, Scope for using your own initiative, Amount of } \\
\text { influence over your job, The work itself. 5-point item } \\
\text { response, high=more satisfied. } \\
\text { Alpha }=0.87 \text { (both years) }\end{array}$ \\
\hline $\begin{array}{l}\text { EJS } \\
\text { scale }\end{array}$ & $3-15$ & 9.62 & 1.10 & 983 & 9.69 & 1.15 & 1079 & $\begin{array}{l}\text { (Satisfaction with ...) Amount of pay you receive, } \\
\text { Training your receive, Your job security. 5-point item } \\
\text { response, high=more satisfied. Alpha }=0.60(2004) \\
\text { and } 0.62(2011)\end{array}$ \\
\hline OC scale & $3-15$ & 10.84 & 1.15 & 984 & 11.30 & 1.15 & 1078 & $\begin{array}{l}\text { (Agreement that ...) Share many of the values of my } \\
\text { organization, Feel loyal to my organization, Proud to } \\
\text { tell people who I work for. 5-point item response, } \\
\text { high=stronger agreement. Alpha }=0.85 \text { (both years) }\end{array}$ \\
\hline $\begin{array}{l}\text { Trust } \\
\text { scale }\end{array}$ & $6-30$ & 19.34 & 2.55 & 984 & 19.72 & 2.61 & 1079 & $\begin{array}{l}\text { (Agreement that managers...) Can be relied on to } \\
\text { keep promises, Are sincere in attempting to } \\
\text { understand employees' views, Deal with employees } \\
\text { honestly, Understand employees having } \\
\text { responsibilities outside work, Encourage people to } \\
\text { develop skills, Treat employees fairly. 5-point item } \\
\text { response, high=stronger agreement. Alpha }=0.93 \\
\text { (both years) }\end{array}$ \\
\hline $\begin{array}{l}\text { Well-being } \\
\text { scales }\end{array}$ & $6-30$ & 18.97 & 1.80 & 984 & 23.54 & 2.09 & 1078 & $\begin{array}{l}\text { (Thinking of past few weeks, how much of the time } \\
\text { has your job made you feel...) (2004) Tense, Calm, } \\
\text { Relaxed, Worried, Uneasy, Content (2011) Tense, } \\
\text { Depressed, Worried, Gloomy, Uneasy, Miserable. 5- } \\
\text { point item response, coded with high=more positive. } \\
\text { Alpha }=0.85 \text { (2004) and } 0.91(2011)\end{array}$ \\
\hline $\begin{array}{l}\text { Perceived } \\
\text { communications } \\
\text { scale }\end{array}$ & $7-35$ & 21.37 & 3.35 & 983 & 22.18 & 3.28 & 1077 & $\begin{array}{l}\text { (How good are managers at keeping you informed } \\
\text { about ...) Changes in how organization is run, } \\
\text { Changes in staffing, Changes in how you do your job, } \\
\text { Financial matters) AND (how good at ...) Seeking } \\
\text { views, Responding to suggestions. Allowing } \\
\text { employees to influence decisions. Alpha }=0.93 \text { (2004) } \\
\text { and } 0.94(2011) \text {. }\end{array}$ \\
\hline
\end{tabular}

Note: All items are coded so that high has positive.sense. Descriptives are at workplace level (workplaces with 50 or more employees and linked employer-employee data), unweighted. Alphas are based on the full employee sample. 


\section{Appendix Table 2: Items Used in Construction of HPWS Measures}

\begin{tabular}{|c|c|}
\hline Domain name & Contents - Year 2004 \\
\hline $\begin{array}{l}\text { Participation } \\
\text { KR20 }=0.78\end{array}$ & $\begin{array}{l}\text { Meeting time; briefing time; subjects discussed in meetings (organization, production, } \\
\text { staffing, finance, planning, pay); consultative committee set up; attitude surveys used; } \\
\text { changes made with employee involvement. }\end{array}$ \\
\hline $\begin{array}{l}\text { Team working } \\
\text { KR20 }=0.67\end{array}$ & $\begin{array}{l}\text { Proportion in teams; task rotation within teams; teams have inter-dependence, } \\
\text { responsibility, autonomy,; team chooses their leader; quality circles used. }\end{array}$ \\
\hline $\begin{array}{l}\text { Development } \\
\text { KR20 }=0.68\end{array}$ & $\begin{array}{l}\text { 'Investor in People' standard achieved ; development included in firm strategy; proportion } \\
\text { given off-job training; proportion given cross-job training; variety of training courses } \\
\text { used; induction courses used; team training; training discussed in briefing groups; } \\
\text { appraisal for non-managers. }\end{array}$ \\
\hline $\begin{array}{l}\text { Selection } \\
\text { KR20 }=0.52\end{array}$ & $\begin{array}{l}\text { selection criteria: qualifications, skills, references, motivation, experience; use personality } \\
\text { tests; use skill tests. }\end{array}$ \\
\hline \multirow[t]{2}{*}{$\begin{array}{l}\text { Incentives } \\
\mathrm{KR} 20=0.68\end{array}$} & $\begin{array}{l}\text { bonus for individual, group/team, workplace, organization performance; profit-sharing for } \\
\text { non-managers; merit-based or performance pay; appraisals that affect pay differentials; } \\
\text { incentives that affect pay differentials. }\end{array}$ \\
\hline & Contents - Year 2011 \\
\hline $\begin{array}{l}\text { Participation } \\
\text { KR20 }=0.78\end{array}$ & $\begin{array}{l}\text { Meeting time; briefing time; subjects discussed in meetings (organization, production, } \\
\text { staffing, finance, planning, pay); consultative committee set up; attitude surveys used; } \\
\text { changes made with employee involvement. }\end{array}$ \\
\hline $\begin{array}{l}\text { Team working } \\
\text { KR20 }=0.67\end{array}$ & $\begin{array}{l}\text { Proportion in teams; task rotation within teams; teams have inter-dependence, } \\
\text { responsibility, autonomy,; team chooses their leader; quality circles used. }\end{array}$ \\
\hline $\begin{array}{l}\text { Development } \\
\text { KR20 }=0.68\end{array}$ & $\begin{array}{l}\text { 'Investor in People' standard achieved; development included in firm strategy; proportion } \\
\text { given off-job training; proportion given cross-job training; variety of training courses } \\
\text { used; induction courses used; team training; training discussed in briefing groups; } \\
\text { appraisal for non-managers. }\end{array}$ \\
\hline $\begin{array}{l}\text { Selection } \\
\text { KR20 }=0.52\end{array}$ & $\begin{array}{l}\text { selection criteria: qualifications, skills, references, motivation, experience; use personality } \\
\text { tests; use skill tests. }\end{array}$ \\
\hline \multirow[t]{2}{*}{$\begin{array}{l}\text { Incentives } \\
\mathrm{KR} 20=0.68\end{array}$} & $\begin{array}{l}\text { bonus for individual, group/team, workplace, organization performance; profit-sharing for } \\
\text { non-managers; merit-based or performance pay; appraisals that affect pay differentials; } \\
\text { incentives that affect pay differentials. }\end{array}$ \\
\hline & Contents - Year 2011 \\
\hline $\begin{array}{l}\text { Participation } \\
\text { KR20 }=0.69\end{array}$ & $\begin{array}{l}\text { Meetings are regular; meeting frequency; staff time in meetings; briefing frequency; } \\
\text { staff time in briefings; subjects discussed in meetings (staffing, finance, investment); } \\
\text { consultative committee; attitude surveys. }\end{array}$ \\
\hline $\begin{array}{l}\text { Team working } \\
\text { KR20 }=0.57\end{array}$ & $\begin{array}{l}\text { Proportion in teams; training for team-working; teams have inter-dependence, } \\
\text { responsibility, autonomy; quality circles used. }\end{array}$ \\
\hline $\begin{array}{l}\text { Development } \\
\text { KR20 }=0.60\end{array}$ & $\begin{array}{l}\text { 'Investor in People' standard achieved ; development included in firm strategy; proportion } \\
\text { given workplace training; proportion given off-job training; proportion given cross-job } \\
\text { training; variety of training courses used; induction courses used; appraisal for managers; } \\
\text { appraisal for all non-managers; employee development is part of workplace strategy; } \\
\text { vacancies filled internally if possible. }\end{array}$ \\
\hline $\begin{array}{l}\text { Selection } \\
\text { KR20 }=0.62\end{array}$ & $\begin{array}{l}\text { selection criteria: qualifications, skills, references, motivation, experience; use personality } \\
\text { tests for manager jobs; use personality tests for non-manager jobs; use skill tests for } \\
\text { manager jobs; use skill tests for non-manager jobs. }\end{array}$ \\
\hline $\begin{array}{l}\text { Incentives } \\
\text { KR20 }=0.81\end{array}$ & $\begin{array}{l}\text { bonus for individual, group/team, workplace, organization performance; profit-sharing for } \\
\text { non-managers; merit-based or performance pay; appraisals that affect pay differentials; } \\
\text { incentives that affect pay differentials. }\end{array}$ \\
\hline
\end{tabular}


Notes: KR20 is the Kuder Richardson reliability measure for dichotomous item scales, computed over whole sample. Underlined items are quantitative banded variables reduced to dichotomies by splitting at the overall median. 'Investor in People' is an externally awarded standard for people development. 